Arkadiusz MODRZEJEWSKI

Uniwersytet Gdański

Dobra Nowina nie ma nic wspólnego z kwestiami ekonomiczno-społecznymi lub narodowymi, nic z demokracja czy międzynarodowa demagogia, nic z nacjonalizmem ${ }^{1}$

Miguel de Unamuno

\title{
Kościół a polityka. \\ Rozważania wokół aktywności politycznej duchowieństwa rzymskokatolickiego podczas wyborów prezydenckich 2010 roku
}

\section{Słowem wstępu}

Kampania przed przyśpieszonymi wyborami prezydenckimi w 2010 roku uzmysłowiła części przynajmniej opinii publicznej w Polsce, a to za sprawą publicystów i komentatorów doniesień medialnych, intelektualistów oraz niektórych polityków - nie tylko lewicowych, o silnej pozycji Kościoła katolickiego w polskim życiu publicznym. Chodzi tu przede wszystkim o rolę polityczną, ale i nie tylko, bo także ekonomiczną, społeczną i kulturową, jaką pełni Kościół w społeczeństwie polskim. Uważa się niekiedy, że Kościół przekroczył ramy swej misji - ewangelizacyjnej i wkroczył na obszary, z których w nowoczesnych państwach został już dawno wyrugowany. Ma to naruszać zasadę świeckości państwa i jego neutralności światopoglądowej oraz zasadę rozdziału (autonomii) państwa od Kościoła. W niniejszym artykule ograniczę się jedynie do ukazania pozycji politycznej polskiego Kościoła. Przy czym kampania prezydencka i udział w niej katolickiego duchowieństwa stanowić będzie jedynie tło szerszego problemu, jakim jest polityczne zaangażowanie Kościoła. Głównym problemem badawczym nie jest zatem pytanie o to, jakie

1 M. Unamuno, Agonia chrystianizmu, w: idem, Agonia chrystianizmu i Dziennik intymny, Warszawa 2010, s. 86. 
są przejawy aktywności politycznej ludzi Kościoła - choć praca ta nie jest wolna od egzemplifikacji, ale o to, co uzasadnia uczestnictwo Kościoła $\mathrm{w}$ polityce.

\section{Kwestie terminologiczne i metodologiczne}

Oczywiście pierwszorzędnym problemem, jaki stoi przed badaczem, analizującym uczestnictwo Kościoła w polityce jest zdefiniowanie kategorii tu podstawowej, czyli pojęcia „Kościół”. W ujęciu teologicznym (eklezjologicznym) w najszerszym znaczeniu przez pojęcie Kościoła rozumie się całą wspólnotę wiernych, stanowiącą Mistyczne Ciało Chrystusa ${ }^{2}$. Jednak wszelkie analizy dotyczące społecznego zaangażowania Kościoła nie odnoszą się do Kościoła tak pojmowanego. Ograniczają się do utożsamienia Kościoła z duchowieństwem, najczęściej z jego górną warstwą, czyli hierarchami. Taki sposób rozumienia Kościoła w odniesieniu do Kościoła katolickiego - nie byłby adekwatny do Kościołów tradycji protestanckiej (ewangelickich i ewangelikalnych) - jest z punktu widzenia eklezjologii katolickiej uzasadniony, gdyż Kościół oprócz atrybutów powszechności posiada też strukturę hierarchiczną. W tym znaczeniu zatem, nieco upraszczając, można stwierdzić, że Kościół rzymskokatolicki to też hierarchia kościelna ${ }^{3}$. I takie rozumienie Kościoła stosuje się w niniejszym artykule. O ile więc używa się tu pojęcia „Kościół” nie ma się na myśli Kościoła w jego uniwersalnym wymiarze, ale w wymiarze, ograniczającym się do jego hierarchicznej struktury, do tzw. Kościoła instytucjonalnego. Włączenie do struktury hierarchicznej odbywa się poprzez udzielanie sakramentu święceń. Stąd też do Kościoła hierarchicznego zaliczają się nie tylko najwyżsi dostojnicy kościelni, ale również osoby duchowne, którym udzielono święceń kapłańskich (prezbiteratu) i diakońskich. Takie podejście jest uprawomocnione nie tylko eklezjologicznie, ale też i przez praktykę językową. W mowie potocznej pojęcie „Kościół”- przez wielkie „," - konotuje zwykle Kościół hierarchiczny. Kiedy mówi się o „działalności Kościoła”, „decyzjach Kościoła” czy też coraz częściej o „patologiach Kościoła”, pojęcie to ogranicza się najczęściej do hierarchii kościelnej lub też w ogólniejszym sensie do duchowieństwa - nie

2 Katechizm Kościoła Katolickiego (dalej cytowany jako KKK), Poznań 1994, nr $781 \mathrm{i} \mathrm{nn.}$

3 Zob. KKK, nr 874 i nn. 
każda osoba duchowna (zakonnice i zakonnicy bez święceń) uczestniczy w strukturze hierarchicznej, nie odnosi się zaś do całej wspólnoty wiernych jako Kościoła uniwersalnego. $Z$ takim wąskim rozumieniem Kościoła mamy też do czynienia $\mathrm{w}$ teorii państwa i prawa, analizującej relacje między państwem a Kościołem pojmowanym jako instytucja, tj. Kościołem instytucjonalnym, który nie jest pojęciem tożsamym z Kościołem jako powszechną wspólnotą wiernych ${ }^{4}$. Aczkolwiek należy zaznaczyć, że Kościół hierarchiczny, instytucjonalny zawiera się w Kościele powszechnym, jest jego częścią. Niemniej odrębną od reszty wiernych jeśli chodzi o zakres uprawnień (misji) i wykonywanych czynności, w tym szczególnie związanych ze sprawowaniem kultu oraz rządzeniem Kościołem ${ }^{5}$.

Problem aktywności politycznej Kościoła może być rozpatrywany z wielu perspektyw teoretyczno-metodologicznych. W tym opracowaniu problem ujęto zarówno z perspektywy teologicznej i prawno-kanonicznej, jak i normatywnej teorii demokracji. Podejście normatywistyczne ma charakter uniwersalny. Stosuje się je w odniesieniu do różnych kontekstów społeczno-kulturowych. Nie odpowiada wszak na pytanie jak i dlaczego Kościół angażuje się w politykę. Ale stara się udzielić w moim przekonaniu odpowiedzi na istotniejsze pytanie o to czy Kościół powinien w ogóle angażować się w politykę. A jeśli tak, to jakie są granice tego zaangażowania $\mathrm{i}$ co je uzasadniania.

\section{Kościół a polityka - perspektywa teologiczna i prawno-kanoniczna}

Truizmem jest twierdzenie, że nie ma jednej doktryny teologicznej. Mamy do czynienia z różnymi szkołami i nurtami w myśli teologicznej. Dlatego też relacja Kościoła do polityki jest różnie interpretowana w zależności od stanowiska doktrynalnego. I tak na przykład teologia wyzwolenia dokonała swoistej syntezy religii i polityki. Religia prowadzić ma do wyzwolenia człowieka, nie tylko duchowego, ale i w sensie społeczno-politycznym oraz ekonomicznym. Teologia wyzwolenia w Ewangelii szuka uzasadnienia dla rewolucji społecznej, dokonującej się w imię sprawiedliwości i godności ludzkiej. Religia ma dać zbawienie, ale nie czekać aż do śmierci człowieka; ma zbawić, a precyzyjniej wybawić, człowieka, już

4 Zob. J. Krukowski, Kościót i państwo, Lublin 1993.

5 KKK, nr 939. 
w świecie doczesnym. Wybawić od niesprawiedliwości społecznej, wyzysku, łamania podstawowych praw człowieka itd. ${ }^{6} \mathrm{~W}$ Ameryce Łacińskiej, skąd wywodzi się teologia wyzwolenia, duchowni nierzadko stawali się liderami grup rewolucyjnych. Do walki o „lepszy świat” wykorzystywali nie tylko ambony, ale organizowali i dowodzili oddziałami zbrojnymi. Na gruncie doktrynalnym w teologii wyzwolenia doszło do syntezy przesłania ewangelicznego i marksistowskiej teorii klas. I chociaż w umiarkowanej wersji tej doktryny teologicznej podkreśla się, że Jezus Chrystus nie był działaczem politycznym, jednak dostrzega się konsekwencje polityczne jego zachowań, które są źródłem „ruchu całkowitego wyzwolenia człowieka",7.

Teologia wyzwolenia została potępiona przez Magisterium Kościoła jako niezgodna z jego oficjalną doktryną. W instrukcji watykańskiej Kongregacji Nauki Wiary z 1984 roku Libertatis nuntius podpisanej przez jej ówczesnego prefekta kard. Josepha Ratzingera zwraca się uwagę na „,dewiacje i ryzyko dewiacji, jakie niosą ze sobą niektóre formy teologii wyzwolenia, uciekające się w sposób niewystarczająco krytyczny do pojęć

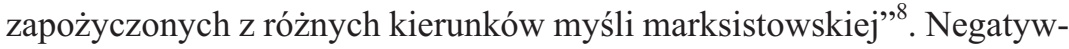
ne stanowisko wobec niej zajął szczególnie papież - Polak Jan Paweł II, który również dostrzegał w niej elementy marksistowskiej teorii walki klas $\mathrm{w}$ istocie sprzecznej $\mathrm{z}$ duchem przekazu ewangelicznego. Podczas pielgrzymki do Meksyku stwierdził: ,[...] obraz Chrystusa polityka, rewolucjonisty, wywrotowca z Nazaretu nie zgadza się z katechezą Kościoła" ".

Związek religii z polityką akceptują również stanowiska fundamentalistyczne - np. niektóre ruchy ewangelikalne w Stanach Zjednoczonych związane z tzw. prawicą chrześcijańską oraz tradycjonaliści katoliccy, skłaniający się niekiedy ku ideom papocezarystycznym (podporządkowanie, przynajmniej w sferze aksjologicznej, państwa Kościołowi) i państwa wyznaniowego, w którym religia i Kościół są ważnymi elementami insty-

6 Zob. B. Mondin, Teologia wyzwolenia, Warszawa 1988, s. $176 \mathrm{nn}$.

7 J. Rollet, Społeczne tło teologii współczesnej, Warszawa 1989, s. 164-167.

8 Kongregacja Nauki Wiary, Instrukcja o niektórych aspektach ,teologii wyzwolenia" Libertatis nuntius, $\mathrm{nr}$ 4, http://www.kns.gower.pl/stolica/nuntius.htm, z dn. 20.09.2010 r.

9 Jan Paweł II, Przemówienie podczas inauguracji III Konferencji Generalnej Episkopatu Ameryki Łacińskiej, Puebla, 28 stycznia 1979, w: Przemówienia i homilie Ojca Świętego Jana Pawła II, Kraków 2008, s. 393. 
tucjonalnymi ładu publicznego. Na gruncie praktyki politycznej Stanów Zjednoczonych oba nurty podjęły współpracę w celu „ewangelizacji” amerykańskiej przestrzeni publicznej, mającej konkretne przełożenie w różnego rodzaju akcjach politycznych, od udzielania poparcia prawicowym politykom, po bojkotowanie klinik aborcyjnych i sprzeciw wobec legalizacji związków homoseksualnych ${ }^{10}$.

Określone doktryny teologiczne nie posiadają jednak sankcji kanonicznej. Dlatego dla niniejszej pracy ważne jest przybliżenie wykładni oficjalnej, tzn. Magisterium Kościoła katolickiego, którego wykładnia jest wiążąca zarówno dla duchowieństwa, jak i wiernych. Za jej nieprzestrzeganie grozi, zwłaszcza duchownym, nałożenie kar kanonicznych, a w tym suspensa, czyli zakaz lub ograniczenie sprawowania czynności związanych z tzw. „,władzą święceń” lub z pełnieniem urzędów kościelnych oraz w poważniejszych przypadkach wydalenie ze stanu duchownego ${ }^{11}$.

Oficjalne stanowisko Kościoła powszechnego względem relacji Kościół-polityka ewaluowało w zasadniczy sposób. Przełomem w tym względzie była likwidacja Państwa Kościelnego w 1870 roku, w wyniku której papieże stracili realną władzę polityczną. Oczywiście nie oznacza to, że Kościół utracił jakąkolwiek zdolność politycznego oddziaływania. W dalszym ciągu Stolica Apostolska prowadziła aktywność dyplomatyczną, zachowując podmiotowość prawnomiędzynarodową. Praktycznie do Soboru Watykańskiego II aktualne było nauczanie papieża Leona XIII - drugiego z „więźniów Watykanu”, odrzucającego ideę rozdziału Kościoła od państwa oraz neutralności religijnej państwa ${ }^{12}$. Poglądom tym dał wyraz

10 Szerzej na ten temat: C. L. Robinson, Doctrine, Discussion and Disagreement: Evangelicals and Catholics Together in the Christian Right, Paper presented during Annual Meeting of Southern Political Science Association, New Orleans, January 3-7, 2006, s. 12.

11 Należy jednak zaznaczyć, że Kodeks prawa kanonicznego nie mówi nic o karach za zaangażowanie polityczne duchownego, tak jak ma to miejsce w przypadku ,uprawniania handlu lub transakcji wbrew przepisom kanonów" (Kan. 1392). Choć, o czym w dalszej części artykułu, zabrania duchownym czynnego udziału w partiach politycznych. Będzie tu w związku z tym mogła mieć zastosowanie jedynie zasada ogólna, w myśl której: „Poza wypadkami przewidzianymi w tej lub w innych ustawach, zewnętrzne naruszenie prawa Bożego lub kanonicznego, tylko wtedy może być ukarane sprawiedliwą karą, gdy domaga się tego szczególna ciężkość przekroczenia i przynagla konieczność zapobieżenia zgorszeniom lub ich naprawienia" (Kan. 1399). Zob. Codex iuris canonici. Kodeks prawa kanonicznego (dalej cytowany jako KPK), Poznań 1984.

12 Zob. J. Krukowski, op. cit., s. 53 i nn.; K. Chojnicka, Nauczanie społeczne Kościoła od Leona XIII do Piusa XII, Kraków 1993, s. 66 i nn. 
w encyklice Immortale Dei poświęconej „państwu chrześcijańskiemu”, w której konstatował, że „państwa nie mogą bez zbrodni tak sobie postępować, jak gdyby Boga zupełnie nie było, lub odrzucać od siebie troskę o religię, jako niepotrzebną i do niczego nieprzydatną, lub wreszcie obojętnie dobierać sobie z wielu religii to, co się właśnie podoba; lecz mają ścisły obowiązek w ten sposób Boga czcić, w jaki sam Bóg nauczył, iż chce być czczony. - A przeto święte powinno być u panujących Imię Boże: jest to jeden z najpierwszych ich obowiązków religię otaczać opieką, życzliwością zasłaniać, powagą swą i prawami bronić, a nic nie ustanawiać i nie zarządzać nic takiego, co by jej bezpieczeństwu było przeciwnym"13.

Istotna zmiana w postrzeganiu relacji państwo-Kościół nastąpiła w Kościele katolickim dopiero w okresie Soboru Watykańskiego II. Kościół przywołując zasadę wolności religijnej, zrezygnował jednocześnie z postulatu katolickiego charakteru państwa ${ }^{14}$. W konstytucji duszpasterskiej Gaudium et spes o roli Kościoła w świecie współczesnym ojcowie soborowi dali temu stosowny wyraz, głosząc, że „Wspólnota polityczna i Kościół są w swoich dziedzinach od siebie niezależne i autonomiczne"15. Przypominali, że właściwe powołanie Kościoła zgodne z duchem ewangelicznym ma charakter religijny. Nie jest to posłannictwo ani polityczne, ani ekonomiczne, ani też społeczne ${ }^{16}$. Dlatego też duchownym zaleca się daleko posuniętą powściagliwość w mieszaniu się w sprawy polityczne, zostawiając sprawy świeckie świeckim ${ }^{17}$. Prawo kanoniczne nie zakazuje angażowania się politycznego księży i zakonników, ale jedynie „przyjmowania publicznych urzędów, z którymi łączy się udział w wykonywaniu władzy świeckiej”"18. Jako że misją Kościoła jest głoszenie Ewangelii i jej pokojowego przesłania, Codex Iuris Canonici zabrania duchownym również „,czynnego udziału w partiach politycznych” i w kierowaniu ,związkami zawodowymi”. Z zakazu tego mogą być zwolnieni przez właściwą

13 Leon XIII, Encyklika Immortale Dei, http://www.opoka.org.pl/biblioteka/W/WP/leon_xiii/encykliki/immortale_dei_01111885.html.

${ }^{14}$ Zob. J. Krukowski, op. cit., s. 58. Zob. Deklaracja o wolności religijnej, w: Sobór Watykański II. Konstytucje, dekrety, deklaracje, Poznań 1967, s. 414-426.

15 Konstytucja duszpasterska o Kościele w świecie współczesnym Gaudium et spes, w: Sobór Watykański II..., nr 76.

16 Ibidem, nr 42.

17 Konstytucja dogmatyczna o Kościele Lumen gentium, w: Sobór Watykański II..., nr 31 .

18 Kan. 285, § 3 KPK. 
władzę kościelną, gdy „będzie wymagała tego obrona praw Kościoła lub rozwój dobra wspólnego" "19. Oczywiście ów przymiotnik „czynny” może być różnie rozumiany. Kodeks nie precyzuje zakresu tego terminu.

Kościół nie zerwał z polityką w sposób radykalny. W dalszym ciągu kontynuuje misję nauczycielską. Ważnym głosem Kościoła w dyskursie politycznym są różnego rodzaju dokumenty, poruszające kwestie społeczne, polityczne i ekonomiczne, w tym szczególnie encykliki papieskie oraz listy pasterskie episkopatów. Zarówno Kościół powszechny, jak i Kościoły partykularne korzystają z prawa zabierania głosu w przestrzeni publicznej. Odcięcie się Kościoła od polityki nie oznacza zatem jego ignorancji w tej materii. Natomiast nie pojawiają się w oficjalnych dokumentach postulaty powrotu do ,idei państwa katolickiego”, które z natury rzeczy stało w opozycji do społeczeństwa pluralistycznego.

Kościół ze swoim nauczaniem społecznym przenika sferę publiczna, jednak dystansuje się, przynajmniej w warstwie deklaratywnej, od czynnego udziału w polityce, oddzielając sferę sacrum - czynności religijne od sfery profanum, w której zakres wchodzi też działalność polityczna. Wykładnia nauczania społecznego kościelnego Magisterium jest formą sakralną i wiąże się ze sprawowaniem przez hierarchów Kościoła urzędu nauczycielskiego. Jeszcze zanim Kościół zrezygnował z przywilejów, jakie dawało mu ,państwo katolickie”, afirmował demokrację jako najwłaściwszą formę rządów. Na początku XX wieku papieże wzbraniali się przed jednoznacznym wskazaniem na to, która forma sprawowania władzy jest najbliższa społecznej nauce Kościoła. Leon XIII w cytowanej już wcześniej encyklice Immortale Dei twierdził, że każdy ustrój jest dopuszczalny, o ile zapewnia rozwój dobra wspólnego. Jednak już Pius XII w 1944 roku wskazywał na demokrację z przymiotnikami „,prawdziwa” i ,zdrowa” jako na odpowiednią dla ówczesnych czasów formę rządzenia. Zapewnia ona pełną partycypację obywateli w systemie politycznym; człowiek traktowany jest w niej podmiotowo, a nie jako bierny element życia społecznego ${ }^{20}$. Kościół swoich wiernych, którzy powołani są do „życia w świecie” i implementacji zasad i wartości chrześcijańskich w przestrzeni publicznej, zachęca do większej aktywności politycznej. W adhortacji Christifideles laici papież Jan Paweł II rzucił radykalne

19 Kan. 287, § 1 i 2 KPK.

20 Zob. P. Mazurkiewicz, Kościół i demokracja, „Civitas. Studia z filozofii polityki” 1999, nr 3, s. 80. 
hasło: „Nikomu nie godzi się trwać w bezczynności”21. Zaangażowanie w działalność polityczną, staje się zatem moralnym obowiązkiem chrześcijan - obywateli ${ }^{22}$. Katolicy mają nie tylko prawo, ale i obowiązek uczestniczenia w polityce. Udział ten powinien przybierać różne formy i dokonywać na różnych płaszczyznach w zależności od predyspozycji i kompetencji jednostek. Postawy biernej nie usprawiedliwiają: „Ani oskarżenia o karierowiczostwo, o kult władzy, o egoizm i korupcję, które nierzadko są kierowane pod adresem ludzi wchodzących w skład rządu, parlamentu, klasy panującej czy partii politycznej, ani dość rozpowszechniony pogląd, że polityka musi być terenem moralnego zagrożenia"23.

\section{Kościół a liberalna demokracja - perspektywa teoriopolityczna}

Obecnie problemem więc nie jest to czy Kościół popiera demokrację, ale to, jak ją rozumie. Ludzie Kościoła zdają się nierzadko ograniczać postrzeganie demokracji do jej procedur, tj. wolnego wyboru władz w oparciu o zasadę powszechności i równości wobec prawa ${ }^{24}$. Natomiast mają trudności z zaakceptowaniem pluralizmu światopoglądowego, będącego conditio sine qua non nowoczesnej demokracji liberalnej. Ów pluralizm zarówno gwarantuje wolność światopoglądową - w tym także katolikom, jak i zabezpiecza przed tendencjami totalistycznymi, narzucającymi innym własny światopogląd promowany jako jedyna, absolutna i powszechna prawda. Kościół ze swej natury jest w opozycji do projektu demokracji liberalnej, gdyż reprezentuje porządek absolutystyczny i to nie tylko w wymiarze organizacyjnym - absolutna władza papieża, ale również, a może przede wszystkim, w znaczeniu epistemologicznym. „Kościelna” teoria poznania opiera się na dogmatach wiary oraz autorytecie hierarchii, a zwłaszcza papieża. Kościół w rozumieniu jego członków jest depozytariuszem absolutnej prawdy objawionej, której „czystości” strzeże Magisterium Kościoła. Demokracja zaś oznacza w istocie epistemologiczny

21 Jan Paweł II, Adhortacja Christifideles laici (dalej cytowane jako CL), nr 3, w: Adhortacje Ojca Świętego Jana Pawła II, t. 1, Kraków 2006.

22 Jan Paweł II, Encyklika Sollicitudo rei socialis, nr 44, w: Encykliki Ojca Świętego Jana Pawła II, Kraków 2007.

${ }^{23} \mathrm{CL}, \mathrm{nr} 42$.

24 Zob. P. Mazurkiewicz, op. cit., s. 81; por. także Jan Paweł II, Encyklika Centesimus annus (dalej cytowana jako CA), nr 46, w: Encykliki Ojca Świętego... 
relatywizm, przynajmniej w wymiarze praktycznym, uznający z jednej strony równość stanowisk $\mathrm{w}$ dyskursie publicznym, z drugiej zaś negujący absolutność jakiegokolwiek stanowiska ${ }^{25}$. I oczywiście każdy z uczestników dyskursu publicznego może być przekonany o posiadaniu absolutnej prawdy, ale jego punkt widzenia nie może być narzucony osobom i grupom, reprezentującym odmienne stanowisko. Totalizacja stanowisk jest zaprzeczeniem demokracji ${ }^{26}$. Kościół w nowoczesnym państwie demokratycznym stoi przed poważnym dylematem czy wycofać się z dyskursu politycznego i przenieść się w przestrzeń prywatną, skoncentrować na kształtowaniu sumień wiernych, czy też raczej aktywnie uczestniczyć w debacie publicznej i bronić reprezentowanego przez siebie stanowiska opartego na przekonaniu o istnieniu uniwersalnej i absolutnej prawdy oraz wierze w powszechne normy etyczne. Aktywny udział Kościoła w polityce wiąże się z podporządkowaniem regułom demokratycznym, w którym decydujący głos należy do większości. Kościół stając się stroną debaty publicznej nie może liczyć na specjalne traktowanie. Staje się on jednym z elementów pluralistycznego ładu. Udzielając poparcia określonym środowiskom naraża się na ataki ich oponentów. Musi liczyć się również z przegraną grup, które popiera i ponieść tego konsekwencje. Nie może korzystać z demokracji tylko do czasu, kiedy przynosi mu ona korzyści, a w przypadku przegranej stronników przenieść się na „pozycje prawa naturalnego i wskazywać na swą «wyjątkową» pozycję"27. Generalnie nie można Kościołowi w imię demokratycznych zasad zabronić uczestnictwa w życiu politycznym, choć projekty takie znane są historii myśli politycznej. Współcześnie jednak przeważa pogląd, że Kościół ma prawo występować jako strona publicznej debaty ${ }^{28}$. Ma prawo aktywizować swoich wiernych do działań w imię takich czy innych wartości i zasad społecznych, ma też prawo wskazywać, na jakie ugrupowania głosować powinno się, a na kogo głosu, by nie popaść w konflikt sumienia, nie powinno się oddawać. Natomiast mając swobodę działania, musi zaakceptować wa-

25 Przed dwudziestoma laty pisał o tym Edgar Morin, konfrontując demokrację zachodnią z systemem komunistycznym (zob. O naturze Zwiazku Radzieckiego, Warszawa 1990).

26 Zob. G. Sartori, Teoria demokracji, Warszawa 1998, s. 243.

27 E. W. Böckenförde, Etos nowoczesnej demokracji a Kościót, „Civitas. Studia z filozofii polityki" 1999, nr 3, s. 42-43.

${ }^{28}$ K. Wandowicz, Demokracja a religia $w$ świetle klasycznych teorii umowy społecznej, „Środkowoeuropejskie Studia Polityczne” 2009, nr 3, s. 203. 
runki demokracji, nie może występować przeciwko nim tylko dlatego, że mogą one obrócić się przeciwko niemu. Za działalność polityczną Kościół może zostać nagrodzony różnego rodzaju przywilejami czy implementowaniem zasad, które głosi. Może jednak też dotychczasowe przywileje stracić. A państwo pod kierownictwem przeciwnych Kościołowi i jego nauczaniu polityków (vide: Hiszpania za rządów José Luisa Zapatero) może odejść od katolickich pryncypiów i realizować wizje Kościołowi przeciwne $^{29}$.

Wobec takiej perspektywy Kościół formułuje własny model demokracji opartej na uniwersalnych i niezmiennych wartościach chrześcijańskich. Obawa przed „dyktaturą większości”, w wyniku której jego pozycja w społeczeństwie i państwie - nie tylko w sensie przywilejów ekonomicznych czy społeczno-politycznych, ale i „rządu dusz” - może ulec marginalizacji, prowadzi Kościół do krytycznego osądu współczesnych systemów demokratycznych, realizujących pryncypia liberalizmu politycznego ${ }^{30}$. Papież Jan Paweł II w encyklice Centesimus annus, sprzeciwiając się takiej formie demokracji, mówił wprost: „Historia uczy, że demokracja bez wartości łatwo przemienia się w jawny lub zakamuflowany totalitaryzm, ${ }^{31}$. Nauka społeczna Kościoła, zarówno w jej oficjalnej i akademickiej wersji, jak i w wersji „ludowej” charakterystycznej zwłaszcza dla dolnej warstwy hierarchii kościelnej, tworzy taki projekt demokracji, w którym pozycja Kościoła byłaby szczególna; miałby on pełnić, przynajmniej implicite, jako depozytariusz prawd objawionych rolę „stróża” wartości uniwersalnych, których żadna wola większości nie może ani znieść, ani też zrelatywizować. Katolicka teoria demokracji odrzuca relatywizm etyczno-epistemologiczny, gdyż wynaturza on prawdziwy sens stosunków demokratycznych. Jan Paweł II zauważał, że „w sytuacji, w której nie istnieje żadna ostateczna prawda, będąca przewodnikiem dla działalności politycznej i nadająca jej kierunek, łatwo o instrumentalizację idei i przekonań dla celów, jakie stawia sobie władza"32. Myśliciele katoliccy z przekonaniem głoszą, że prawdziwa demokracja jest możliwa tylko wtedy, gdy podtrzymują ją i umacniają religijne i moralne wartości

29 E. W. Böckenförde, op. cit., s. 42.

30 Zob. Sz. Ossowski, Jan Pawet II a demokracja, ,Środkowoeuropejskie Studia Polityczne" 2007, nr 1, s. 123 i nn.; także G. D. Glenn, J. Stack, Is American Democracy Safe for Catholics?, „The Reviews of Politics” 2000, nr 1, s. 21-22.
$31 \mathrm{CA}, \mathrm{nr} 46$.
$32 \mathrm{CA}, \mathrm{nr} 46$. 
i zasady, które ograniczają omnipotencję władzy wybranej wolą większości i z tej większości czerpiącej legitymizację. A Kościół postrzegany jest jako skuteczny nauczyciel i duszpasterz w sprawach publicznych ${ }^{33}$.

\section{Kościół polski w kampanii prezydenckiej 2010 roku}

W polskiej rzeczywistości politycznej znaczenie Kościoła katolickiego trudno przecenić. Jest on ważnym elementem ładu publicznego, który od samego początku państwa polskiego wykracza poza sferę sakralną i aktywnie uczestniczy w życiu politycznym. Role, jakie pełnił w przeszłości, zwłaszcza w okresie zaborów - jako ostoja polskości oraz w czasie okupacji hitlerowskiej i w Polsce Ludowej, utrwaliły nie tylko stereotypowy obraz Polaka - katolika, ale w pewnym sensie też legitymizują po dziś dzień jego pozycję w systemie politycznym jako aktywnego podmiotu, będącego jednocześnie grupą nacisku, uprzywilejowanym uczestnikiem debaty publicznej oraz ośrodkiem kształtującym i kreującym postawy i zachowania obywateli. Znaczna część duchowieństwa, także wyższej hierarchii, zdając sobie sprawę ze społecznej legitymizacji Kościoła jako ośrodka aktywności politycznej, próbuje implementować niektóre zasady państwa wyznaniowego. Charakterystyczne są na przykład starania polskich biskupów - jednym z nielicznych wyjątków był bp Tadeusz Pieronek - o wprowadzenie do preambuły Konstytucji archaicznego invocatio Dei, które w ich ocenie mogłoby być pomocne również przy jej interpretacji ${ }^{34}$. Od końca lat 80. następuje sakralizacja polskiej przestrzeni publicznej. Symbole religijne obecne są $\mathrm{w}$ instytucjach publicznych na każdym poziomie władzy, w szkołach, domach opieki społecznej, w zakładach pracy. Państwo świeckie jest w defensywie przed roszczeniami Kościoła, obejmującymi tak sferę symboliczną, jak ekonomiczno-organizacyjną i ustrojową. Uczestnictwo duchowieństwa w polityce przejawiało się aktywnym wspieraniem środowisk powołujących się na społeczną naukę Kościoła oraz przywiązanie do tradycji narodowo-katolickich. Działalność polityczna nie była jednak zjawiskiem powszechnym wśród duchownych. Wielu z nich dystansowało się od bieżącej polityki i udzielania wyraźnego

33 Zob. G. Weigel, Stateczna rewolucja. Kościół sprzeciwu a upadek komunizmu, Poznań 1995, s. 256.

34 Zob. R. Graczyk, Konstytucja dla Polski. Tradycje, doświadczenia, spory, Kraków-Warszawa 1997, s. 205 i nn. 
poparcia jakiejś formacji politycznej. Angażowanie się w kampanie polityczne konkretnych polityków i ugrupowań było z reguły charakterystyczne dla zachowawczej części episkopatu oraz niższego duchowieństwa parafialnego, wśród którego przeważają postawy tradycjonalistyczne, opozycyjne względem etosu inteligenckiego i progresywizmu katolickiego. Symbolem ,integrystów” stało się redemptorystyczne Radio Maryja. Dyrektor toruńskiej rozgłośni katolickiej o. Tadeusz Rydzyk stał się aktywnym promotorem karier politycznych. Radio w istotny sposób wpływało na postawy polityczne swoich słuchaczy, kształtując w nich nie tyle postawę obywatelska, co przywiązanie do określonego środowiska politycznego uznanego za gwaranta katolickości i polskości państwa. Duchowieństwo reprezentujące tzw. „Kościół otwarty” nawet jeśli wypowiadało się na tematy polityczne, zazwyczaj powstrzymywało się od bezpośrednich deklaracji poparcia, stawiając sobie za cel „cywilizowanie” ładu publicznego w duchu ewangelicznych ideałów pojednania i pokoju, zgodnie z katolicką tradycją filozoficzno-teologiczną.

Kościół jest obecny w polskiej przestrzeni politycznej od początku transformacji. Jego realny wpływ na politykę od końca lat 80. stopniowo wzrasta. I dotyczy to zarówno skali krajowej, jak i lokalnej, gdzie aktywność wyborcza duchownego, opowiadającego się w sposób jawny za określonym kandydatem czy komitetem, może wpłynąć na przebieg wyborów w o wiele większym stopniu niż na płaszczyźnie krajowej, gdzie społeczeństwo jest bardziej zdywersyfikowane pod względem utożsamiania się z religią i Kościołem. Zmianie ulega jedynie stopień natężenia aktywności politycznej duchowieństwa. Z pewnością o silnym poparciu, jakiego część duchownych w sposób niezawoalowany udzieliła kandydatowi Prawa i Sprawiedliwości w dużej mierze zdecydowała aura wokół katastrofy smoleńskiej. Księża poczuli misję obrony ojczyzny i tradycyjnych wartości. Prowadziło to do jawnych deklaracji poparcia, jak na przykład w przypadku kilku księży profesorów Uniwersytetu Papieskiego w Krakowie, ale częściej w sposób bardziej łamiący zasadę oddzielenia sfery sacrum od profanum deklaracje i nawoływania padały podczas nabożeństw i kazań.

Prawo i Sprawiedliwość z Jarosławem Kaczyńskim zostało przez sporą część polskiego duchowieństwa uznane za ostoję polskości. Ugrupowaniu temu przypadła zaszczytna rola w ad hoc wyłaniającej się neomesjanistycznej historiozofii. Historiozofii nie akademickiej bynajmniej, lecz mającej znamiona czegoś na kształt historiosophia pauperum, w której malowane zostały wyraźne obrazy walki dobra ze złem, katolicyzmu 
z laicyzmem, polskości z liberalnym kosmopolityzmem i odwiecznymi wrogami Polski. I choć kampania kandydata PiS przebiegała w dość łagodny sposób, wyczuwalne było podskórne wrzenie tej części elektoratu, która utożsamiała się z tradycjonalizmem katolickim, z jego uproszczonym modelem świata, ze stereotypami i lękami. Wstrzemięźliwością nie wykazali się najwyżsi hierarchowie polskiego Kościoła publicznie udzielający swojego poparcia Jarosławowi Kaczyńskiemu. Ich postawa była na tyle wyraźna, że bp Pieronek na łamach „Rzeczpospolitej” skonstatował, że polscy biskupi są „zadymieni PiS-em”35.

Jawne poparcie jednego z kandydatów w wyścigu prezydenckim wiąże się w mojej ocenie ze słabnącą rolą Kościoła w społeczeństwie polskim. Rosnąca pozycja w państwie nie oznacza jednocześnie rosnącej pozycji w społeczeństwie. Paradoksalnie wzrostowi wpływów politycznych Kościoła w państwie, towarzyszy wzrost natężenia postaw kontestujących te wpływy. Topnieje Kościołowi nie tylko liczba wiernych, a zwłaszcza czynnych katolików, ale również zarysowuje się ideologiczna przepaść między nauczaniem kościelnych hierarchów a poglądami i postawami wiernych $^{36}$. Kampania przypadła nie tylko w okresie przedłużającej się żałoby narodowej, co oczywiście miało znaczenie przede wszystkim emocjonalne - zapewne w dużej mierze skłoniło duchownych do udzielania poparcia Jarosławowi Kaczyńskiemu, ale również w okresie debat, w których stroną byli ludzie Kościoła. Można zatem przypuszczać, że taktyka, polegająca na udzieleniu poparcia osobie w sposób jednoznaczny deklarującej posłuszeństwo doktrynie katolickiej i jej lokalnym interpretacjom opierała się też na racjonalnej kalkulacji zysków i strat. Kościół w Polsce znalazł się w dość kłopotliwej dla niego sytuacji. Z jednej strony niejasności wokół Komisji Majątkowej, z drugiej opór większości obywateli przeciwko zwiększaniu wpływów Kościoła, w tym także przeciwko narzucaniu przez Kościół własnych wizji etycznych, czego najbardziej medialnym przykładem była dyskusja wokół zapłodnienia pozaustrojowego nazywanego popularnie in vitro. Duchowni byli zatem bardziej skłoni poprzeć

35 Zob. „Rzeczpospolita” 2.09.2010.

36 Ta tendencja utrzymuje się już od kilkunastu lat. Mimo dosyć wysokiej frekwencji podczas nabożeństw i składanych deklaracji, polscy katolicy traktują religię bardzo pragmatycznie, czerpiąc z katolicyzmu to, co przynosi im korzyść, ignorując natomiast postulaty, które kolidują z ich wewnętrznym światopoglądem i praktyką codziennego dnia (zob. T. Szawiel, Kościól polski-spojrzenie z zewnatrz, „Civitas. Studia z filozofii polityki” 1999, nr 3, s. 127 i nn.). 
tego kandydata, który w odżywającym konflikcie światopoglądowym i ideologicznym o kształt państwa, dawał większą gwarancję kontynuacji niż zmiany. Choć wybór Bronisława Komorowskiego wcale nie oznacza w tym względzie jakichkolwiek rewolucyjnych przemian. Jednak ostentacyjnie deklarowana katolickość Jarosława Kaczyńskiego stała się dla części duchownych dostateczną przesłanką, by udzielić mu swojego poparcia.

Jak już wspomniano, w kampanii duchowni nierzadko wykorzystywali ambony, łamy katolickiej prasy oraz media elektroniczne. Niektórzy, jak pięciu profesorów Uniwersytetu Papieskiego w Krakowie, posunęło się do wejścia w skład komitetu poparcia Jarosława Kaczyńskiego, co wywołało nawet reakcję władz Uczelni, dystansujących się od aktywności politycznej własnych pracowników ${ }^{37}$. I właśnie aktywność tych przedstawicieli Kościoła budzi największe wątpliwości. Bo jak opinia publiczna w Polsce przyzwyczaiła się do politycznych wystapień duchownych podczas nabożeństw i wystąpień medialnych, tak od dawna nie spotkała się $\mathrm{z}$ tak zdecydowanym poparciem. I nie chodziło tu o wiejskich proboszczów ani o prowincjonalnych biskupów, ale o krakowskich uczonych, którzy wykorzystali swoje imię - i nie tylko, bo także tytuły naukowe i kościelne, a pośrednio autorytet Uczelni i Kościoła. Tłumaczenie jednego z grupy księży było następujące: „Nie poparliśmy Kaczyńskiego w imieniu uczelni, ale jako osoby prywatne. Trzeba rozdzielić dwie rzeczy. Moje duszpasterzowanie i moje poglądy jako osoby prywatnej. Nigdy podczas kazania i w kontaktach z wiernymi nie agitowałem i nie agituję za jakimkolwiek politykiem. Mam jednak prawo do wstępowania do komitetów i stowarzyszeń, które są bliskie moim ideałom"38.

Pozostaje jednak wątpliwość czy osobie duchownej wolno wchodzić w skład jakiegokolwiek komitetu poparcia kandydata na funkcję publiczną? Jeśli agitacja z ambony jest wyrazem ignorancji, nieznajomości podstaw wiary, to w tym przypadku ani o ignorancji, ani nawet o wykorzystywaniu przysłowiowej ambony do celów politycznych nie ma mowy. Prawo kanoniczne mówi jedynie o zakazie czynnego udziału w partiach politycznych, czego z pewnością znamion nie wyczerpuje wejście w skład komitetu popierającego kandydata na prezydenta. Natomiast postawa ta

37 Zob. D. Wielowiejska, Kościót i PiS: jak daleko, jak blisko, http://wyborcza.pl/1,76842,7933992,Kosciol_i_PiS_jak_daleko_jak_blisko.html.

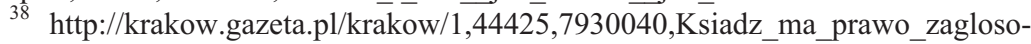
wac_na_Jaroslawa_Kaczynskiego.html. 
zasadniczo kłóci się z Magisterium Kościoła, oddającym sprawy polityczne w ręce świeckich, pozostawiając jedynie margines duchownym, w sytuacji, w której realnie zagrożone są prawa człowieka i obywatela. Pozostaje także w kolizji z apolitycznością Kościoła. Tak jak naruszeniem zasad demokracji jest polityczne zaangażowanie niektórych grup zawodowych: sędziów, prokuratorów, czynnych żołnierzy i policjantów, tak przez analogię można doszukać się naruszenia podstaw demokracji przez czynny udział duchowieństwa w bieżącej polityce. Oczywiście zasada inkluzywnego obywatelstwa nie wyłącza duchownych z systemu demokracji ${ }^{39}$, niemniej ich aktywne poparcie może prowadzić do zaburzenia proporcji ${ }^{40}$. W państwie, w którym dominuje jedno wyznanie, polityczna aktywność ludzi Kościoła, może przeszkodzić w racjonalnym wyborze kandydata oraz przyczynić się do marginalizacji kandydatów niepopieranych przez Kościół. Zaangażowanie polityczne ludzi Kościoła w politykę godzi też w ideę państwa świeckiego i oznacza naruszenie zasady rozdziału Kościoła od państwa. Duchowny nie jest osobą prywatną po godzinach urzędowania, podobnie jak nie jest nią sędzia, prokurator, rektor uniwersytetu czy komendant policji. Prawo kanoniczne nie zwalnia z zakazu działalności politycznej po wypełnieniu czynności liturgicznych i zakończeniu pracy w kancelarii parafialnej. Stan duchowny przyjmuje się wraz ze święceniami kapłańskimi i trwa on aż do śmierci bądź specjalnej dyspensy udzielanej przez Stolicę Apostolską. Jako reprezentant Kościoła instytucjonalnego duchowny nie może zatem działać w sferze polityki w takim samym stopniu jak świecki obywatel, nie naruszając przy tym wspomnianej zasady rozdziału Kościoła od państwa.

\section{Zamiast zakończenia}

Kościół polski od dziesięcioleci zdaje się nie zauważać kardynalnego błędu, jaki popełniają jego reprezentanci. Angażowanie się w politykę nie

39 Zob. R. Dahl, O demokracji, Kraków-Warszawa 2000, s. 87.

${ }^{40}$ Co innego gdyby poparcia udzielali nie używając tytułów kościelnych i naukowych (ksiądz, profesor), ale dokonali go jedynie pod własnym imieniem i nazwiskiem. Wówczas, jeśli chodziłoby nie o osoby powszechnie znane, żadnego naruszenia zasad demokratycznych nie można byłoby się doszukać. Jednak tego typu poparcie dla kandydata byłoby bezwartościowe. Dopiero konotacje instytucjonalne sprawiają że udzielający poparcia jest człowiekiem, z którego zdaniem należy się liczyć, mogącym swoim przykładem przyciagnąć jakąś grupę zwykle niezdecydowanych jeszcze wyborców. 
tylko nie licuje z soteriologiczną misją Kościoła, ale też rodzi sprzeciw wiernych niechętnych politycznej aktywności księży, co w istocie osłabia pozycję Kościoła w społeczeństwie. Nie istnieją żadne przesłanki ani teologiczne, ani też teoripolityczne uzasadniające zaangażowanie duchownych w politykę. Aktywność duchownych w ostatniej kampanii przed wyborami prezydenckimi nie była niczym nowym w polskiej rzeczywistości politycznej. Zdziwienie komentatorów i obserwatorów sceny politycznej budzić może jedynie stopień natężenia i determinacji, z jakim niektórzy duchowni zaangażowali się w tę kampanię. Jakie mogą być tego konsekwencje? Doświadczenie społeczeństw zachodnich pokazuje, że nieodwracalnym trendem jest nie tylko redukcja liczby praktykujących wiernych, ale i zmniejszanie wpływów Kościoła w sferze publicznej. Polska demokratyczna, mając za sobą okres komunistycznej laicyzacji, rekompensowała Kościołowi straty poniesione przed 1989 rokiem. Jednak należy się spodziewać, także po radykalnej postawie niektórych duchownych, że „tłuste lata” Kościoła katolickiego w Polsce dobiegają końca. Spodziewana jest laicyzacja państwa i pogłębienie indyferentyzmu religijnego społeczeństwa. Zbyt silny udział Kościoła w polityce, paradoksalnie proces ten może tylko przyspieszyć.

\section{Summary}

The campaign preceding the early presidential elections in 2010 reminded Polish society of the strong position the Catholic Church holds in political life, and mainly its role in the political system. In the context of the latest elections, it was observed that the Church went beyond the framework of its evangelization mission to enter realms it has long been driven out from in other modern states. This breaches the principle of the secular character of the state, its neutral point of view and separation (autonomy) of state and Church. This paper is limited to the presentation of the Polish Church's political standpoint. The involvement of Catholic clergy in the presidential campaign serves only as a background to present the larger problem of political involvement of the clergy in general. Therefore, the main research issue is not the question of the forms of political activity which members of the Church assume, although some exemplifications are present in this paper, but rather what justifies the involvement of the Church in politics. It is demonstrated that neither theological doctrine nor the normative theory of democracy sufficiently justifies the active participation of the clergy in politics. It is also stressed, however, that the Church cannot be prohibited from partaking in public debate unless democratic principles are breached. Yet the Church's involvement needs to fulfill one condition: it has to approve the principles of democratic discourse, such as the equal rights of different standpoints and the approval of the principle of relativity in political communication. 